\title{
EKSISTENSI HIBURAN KIBOT PADA ACARA RESEPSI PERNIKAHAN MASYARAKAT TAMIANG
}

\author{
Abdul Robby, Rakhmadsyah Putra Rangkuty ${ }^{1)}$ \\ ${ }^{1}$ Program Studi Sosiologi FISIP Universitas Malikussaleh, oecoex@gmail.com
}

\begin{abstract}
This research focuses on the causes of kibot entertainment still exist in Tamiang society and the motives of people choosing kibot as entertainment. Coleman's rational choice theory was used in analyzing research data. The research method is a qualitative approach with data collection techniques such as observation, interviews, and documentation. Meanwhile, the data analysis technique in this study used an interactive analysis method. The research findings illustrate that people see kibot as a rational choice based on economic value considerations because of its affordable prices. Kibot entertainment also has social value as a prestige that is given through the recognition of others. In addition, the existence of kibot entertainment is based on the guidance of people around them who help them with their work at the wedding reception. On the basis of these motives, kibot entertainment continues to exist in demand by the Tamiang community, especially the people of Kampung Babo.
\end{abstract}

ABSTRACT

Keywords: Existence, Kibot, Rational Choice

\begin{abstract}
ABSTRAK
Penelitian ini berfokus pada penyebab hiburan kibot masih eksis di tengah masyarakat dan motif masyarakat memilih kibot sebagai hiburan. Teori pilihan rasional Coleman digunakan dalam menganalisis data penelitian. Metode penelitian yaitu pendekatan kualitatif dengan teknik pengumpulan data berupa observasi, wawancara, dan dokumentasi. Sementara teknik analisis data dalam penelitian ini menggunakan metode analisis interaktif. Temuan penelitian menggambarkan masyarakat melihat kibot sebagai sebuah pilihan rasional atas pertimbangan nilai ekonomi karena harga yang terjangkau. Hiburan kibot juga memiliki nilai sosial sebagai sebuah prestise atau gengsi yang diberikan melalui pengakuan orang lain. Selain itu, eksistensi hiburan kibot dilandasi oleh tuntunan dari orang-orang sekitar yang membantu pekerjaan mereka dalam acara resepsi pernikahan. Atas dasar motif-motif tersebut menjadikan hiburan kibot tetap eksis diminati oleh masyarakat Tamiang khususnya masyarakat Kampung Babo.
\end{abstract}

Kata Kunci: Eksistensi, Kibot, Pilihan Rasional 


\section{PENDAHULUAN}

Keberadaan masyarakat tidak terlepas dari keberadaan budayanya yang diwariskan secara turun-temurun dan dibawa kemana pun mereka berada. Menurut Soekanto (2010) yang dimaksud dengan masyarakat adalah orang yang hidup bersama dan menghasilkan kebudayaan. Tidak ada masyarakat yang tidak mempunyai kebudayaan dan sebaliknya tidak ada kebudayaan tanpa masyarakat sebagai wadah pendukungnya. Seni sebagai sebuah kebudayaan berkembang sesuai dengan keadaan lingkungan dan dinamika peradaban masyarakat yang berbeda-beda di wilayah Indonesia. Suku-suku bangsa di wilayah Aceh memiliki bentuk-bentuk seni budaya sebagai ciri khas yang merepresentasikan keberagaman, kekayaan, dan identitas kedaerahan.

Salah satu bentuk seni budaya tersebut adalah seni musik. Masyarakat Aceh Tamiang juga memiliki seni musik, yang pada mulanya dikenal dengan sebutan Dendang Sayang dan Debus yang pada saat itu merupakan hiburan yang bernuansa islami. Pada tahun 1960-an, ketoprak, ludrok, dan wayang dibawa oleh transmigran dari Pulau Jawa ke Tamiang dan populer sampai akhir tahun 1970-an. Kemudian pada tahun 1980-an akhir sampai 1992 masuk musik band dan orkes ke Tamiang dengan dilengkapi berbagai alat musik seperti gitar, bass, sruling, gendang, accordion, piano, dan biola yang dimainkan dalam satu panggung. Kemudian pada tahun 1993 sampai sekarang masuk hiburan kibot ke Tamiang sampai pelosok-pelosok daerah (observasi dan wawancara dengan beberapa informan, 20/01/2018).

Sejak awal tahun 1993 pertunjukan hiburan tidak lagi mengedepankan konsep islami, malah yang terjadi sebaliknya. Masuknya hiburan kibot yang bernuansa erotis dengan goyangan dan musik yang lebih modern, dibawakan oleh penyanyi perempuan atau dikenal dengan istilah "biduan" yang membawakan lagu dari jenis DJ, house, dangdut house, dangdut remix, pop remix, dan semacamnya. Para biduan umumnya mengenakan busana ketat yang minim seperti rok pendek, baju ketat, ataupun pakaian dengan banyak celah di bagian atas serta pinggul agar mengeluarkan kesan keerotisan dan keseksian ketika bergoyang di atas panggung. Tidak hanya itu, apabila telah lewat tengah malam biduan "kibot bongkar" melepaskan baju dan roknya sehingga nyaris tidak memakai busana (observasi dan wawancara dengan beberapa informan, 20/01/2018).

Akan tetapi hiburan musik kibot erotis ini menuai pro dan kontra di dalam masyarakat yang kemudian direspon oleh Pemerintah Kabupaten Aceh Tamiang karena sebagian masyarakat berpendapat bahwa hiburan kibot ini tidak sesuai adat istiadat hiburan musik Melayu, bahkan membunuh identitas budaya dan adat istiadat masyarakat Tamiang. Di samping itu, hiburan ini menimbulkan berbagai persoalan baru seperti minuman alkohol, perjudian, narkoba, dan lain-lain (Ramadhan, 2014).

135 | Jurnal Ilmu Sosial dan Ilmu Politik Malikussaleh (JSPM) Volume 1 Nomor 2 Tahun 2020 
Pemerintah Kabupaten Aceh Tamiang selanjutnya mengeluarkan Qanun Nomor 11 Tahun 2008 tentang Izin dan Tata Cara Penyelenggaraan Hiburan, yang bertujuan untuk mengatur, mengawasi, mengendalikan, dan menata kegiatan penyelenggaraan hiburan dengan berpedoman pada peraturan perundang-undangan. Izin yang dimaksud dikeluarkan oleh Dinas Syariat Islam Kabupaten Aceh Tamiang atau Kantor Pelayanan Perizinan Terpadu Satu Pintu sebagai tanda bukti bahwa hiburan itu layak diselenggarakan baik hiburan yang bersifat komersil maupun nonkomersil (https://jdih.acehprov.go.id).

Keresahan masyarakat terhadap hiburan kibot dikarenakan aktivitas ini menimbulkan berbagai masalah terutama pada kalangan muda-mudi. Merespon hal tersebut Kepala Dinas Syariat Islam Aceh Tamiang mengeluarkan keputusan bersama tentang larangan bagi Datok (Kepala Desa) untuk mengeluarkan izin/rekom hiburan kibot sampai malam hari. Batas waktu yang dibolehkan sampai pukul 18.00 WIB (http://aceh.tribunnews.com). Keputusan bersama itu juga merupakan respon terhadap insiden pemukulan Kepala Dinas Syariat Islam Kota Langsa bersama personel WH ketika membubarkan hiburan kibot di Kampung Karang Anyar, Kecamatan Langsa Baro, Minggu malam, 25 Agustus 2013. Tindak kekerasan yang menimpa tim Dinas Syariat Islam Kota Langsa tersebut telah memicu reaksi berbagai pihak, termasuk mahasiswa dan ormas Islam (http://aceh.tribunnews.com).

Pada Desember 2015 lalu, MPU Aceh Tamiang melaksanakan rapat koordinasi antar lembaga Pemerintah dan organisasi masyarakat, dengan tujuan memperkuat ukhuwah kebersamaan dalam pelaksanaan Syari'at Islam secara kaffah di Kabupaten Aceh Tamiang. Kegiatan itu diikuti oleh para Kepala KUA, Camat, Hakim dalam lingkungan Mahkamah Syari'ah, anggota MPU dan DKU, serta ormas Islam. Sebagai salah satu wujud kebersamaan, pada saat itu Forum Rapat Koordinasi mengeluarkan surat edaran bersama antara Forkompimda dengan Forkompimda Plus tentang larangan hiburan malam termasuk kibot (https://aceh2.kemenag.go.id).

Masyarakat Kampung Babo Kecamatan Bandar Pusaka dan sekitarnya pada tahun 19932010 masih sangat antusias dengan hiburan kibot, terbukti dengan seringnya kibot dilangsungkan sampai menjelang waktu Shubuh. Ketika itu masyarakat Kampung Babo khususnya muda-mudi menjadikan hiburan kibot sebagai ajang pertemuan dan perkumpulan. Hiburan kibot juga dijadikan sebagai tempat perjudian, narkoba, dan minuman keras sehingga sebagian masyarakat merasa resah dengan hal tersebut dan melaporkannya ke pihak Pemerintah Kampung. Pemerintah Daerah juga merespon dan memandang kegiatan hiburan kibot sebagai perbuatan yang merusak Syari'ah dan meresahkan masyarakat dengan masalah sosial yang ditimbulkannya. Untuk itu Pemerintah

136 | Jurnal Ilmu Sosial dan Ilmu Politik Malikussaleh (JSPM) Volume 1 Nomor 2 Tahun 2020 
mengeluarkan Himbauan dan Qanun tentang pelaksanaan hiburan malam seperti yang telah disebutkan di atas (observasi dan wawancara dengan beberapa informan, 10/07/2018).

Pada tahun 2010 sampai sekarang memang terjadi banyak perubahan terhadap penyelenggaraan hiburan kibot, seperti pada pakaian biduan yang tidak lagi sampai nyaris tanpa busana, walaupun tetap menggunakan busana yang menonjolkan keseksian (observasi dan wawancara dengan beberapa informan, 11/07/2018). Masyarakat Kampung Babo dan sekitarnya sampai sekarang masih menggunakan hiburan kibot dalam acara resepsi pernikahan dan sunat rasul. Sebagian masyarakat Kampung Babo melangsungkan hiburan kibot sampai batas waktu sesuai himbauan Pemerintah Kabupaten Aceh Tamiang. Tetapi sebagian masyarakat yang lain tidak menghiraukan himbauan tersebut dan melangsungkan hiburan kibot sampai malam, tepatnya sampai tengah malam antara pukul 20:00 WIB sampai 24:00 WIB (observasi dan wawancara dengan beberapa informan, 12/07/2018).

Walaupun penyelenggaraan hiburan kibot sampai malam terdapat pro dan kontra tetapi kibot masih tetap eksis sampai sekarang. Untuk hal itu peneliti tertarik mengetahui motif-motif masyarakat Kampung Babo melangsungkan kibot sampai malam hari. Berdasarkan hal tersebut di atas, penulis tertarik untuk meneliti pandangan masyarakat terhadap larangan hiburan kibot. Oleh karena itu penulis berkeinginan untuk membuat satu kajian penelitian dengan judul: "Eksistensi Hiburan Kibot pada Acara Resepsi Pernikahan Masyarakat Tamiang (Studi di Kampung Babo Kecamatan Bandar Pusaka Kabupaten Aceh Tamiang)”.

Penelitian terdahulu yang membahas masalah yang sama pernah dilakukan oleh Ramadhan (2014) pada masyarakat Tamiang dan Zai (2014) pada masyarakat suku Nias. Penelitian sejenis juga dilakukan oleh Sakrina (2017) dan Bakti (2020) pada masyarakat suku Gayo. Namun beberapa studi tersebut berfokus pada masalah perubahan sosial budaya, konflik, dan struktur-struktur yang berhubungan dengan hiburan kibot. Sementara studi yang akan penulis lakukan berfokus pada masalah pilihan rasional pengguna jasa kibot sehingga membuat jenis hiburan tersebut eksis di dalam resepsi pernikahan masyarakat Tamiang.

\section{Teori Pilihan Rasional James S. Coleman}

Teori ini dikembangkan oleh James S. Coleman melalui jurnalnya pada tahun 1989 yang berjudul Rationality and Society sehingga menjadi salah satu teori hebat dalam sosiologi masa kini. Pada tahun 1990 Coleman menerbitkan buku yang sangat berpengaruh, Foundation of Social Theory berdasarkan perspektif pilihan rasional (Ritzer, 2008). Teori pilihan rasional memusatkan perhatian pada aktor. Aktor dipandang sebagai manusia yang mempunyai maksud dan tindakannya 
tertuju pada upaya untuk mencapai tujuan itu. Aktor dipandang mempunyai pilihan (preferensi) atas keperluan dan nilai (Coleman, 2008; Ritzer, 2008).

Berdasarkan teori pilihan rasional, masyarakat Kampung Babo dalam bertindak memilih hiburan kibot pada acara pernikahan atas dasar nilai ekonomi. Hiburan kibot lebih terjangkau dibandingkan dengan hiburan musik lainnya seperti band dan orkes. Penggunaan hiburan dipercaya dapat meningkatkan jumlah tamu undangan. Ketika tamu undangan yang datang lebih banyak diharapkan memperoleh kompensasi atau bentuk dukungan berupa amplop, barang, atau jasa untuk menutupi biaya hajatan pernikahan. Dalam kaitannya dengan jasa secara umum Tuan Rumah menghadirkan hiburan Tuan rumah menjadikan hiburan kibot sebagai daya tarik dan hiburan bagi para muda-mudi atau masyarakat yang sedang "rewang" agar lebih bersemangat dalam bekerja. Atas dasar itu masyarakat Babo memandang terdapat nilai atas pilihan dan tindakan yang dilakukan untuk mencapai tujuan yang sesuai dengan tingkatan pilihannya.

\section{METODE PENELITIAN}

Penelitian ini dilakukan di Kampung Babo, Kecamatan Bandar Pusaka, Kabupaten Aceh Tamiang. Kampung Babo terletak $\pm 30 \mathrm{Km}$ dari jalan Medan Banda Aceh atau Kota Kuala Simpang. Lokasi ini dipilih dikarenakan masyarakat Kampung Babo memiliki kebiasaan pada acara resepsi pernikahan menggunakan kibot sebagai hiburan. Penelitian ini menggunakan pendekatan kualitatif dengan tipe deskriptif yang menghasilkan data berupa kata-kata tertulis dan lisan dari orang-orang atau perilaku yang diamati (Moleong, 2009). Untuk memperoleh data yang dibutuhkan dalam penelitian ini penulis menggunakan teknik penelitian lapangan, yaitu penelitian secara langsung ke lokasi dengan maksud untuk mendapatkan data dan fakta yang ada kaitannya dengan masalah yang diteliti. Informan penelitian ini meliputi terdiri dari beberapa macam kriteria, yaitu:

a. informan kunci, yaitu mereka yang mengetahui dan memiliki berbagai informasi pokok yang diperlukan dalam penelitian ini diantaranya tuan rumah dan pemain hiburan kibot.

b. informan utama, yaitu mereka yang terlibat langsung dalam interaksi sosial yang diteliti diantaranya Datok Penghulu Kampung Babo dan tokoh masyarakat.

c. Informan tambahan, yaitu mereka yang dapat memberikan informasi walaupun tidak langsung yang terlibat dalam interaksi sosial yang diteliti diantaranya masyarakat Kampung Babo yang pernah melihat hiburan kibot pada malam hari. Seluruh informan dipilih berdasarkan kebutuhan penelitian. 
Sumber data terdiri atas data primer dan data sekunder (Sugiyono, 2013). Data primer diperoleh dari wawancara, observasi partisipatif, dan dokumentasi. Sedangkan data sekunder diperoleh dari studi kepustakaan. Adapun analisis data dilakukan secara interaktif dan terdiri atas tiga komponen, yakni reduksi data, penyajian data, dan verifikasi.

\section{HASIL DAN PEMBAHASAN}

\section{Gambaran Umum Kibot Tigan}

Terdapat sebuah hiburan kibot yang bernama Tigan di Kampung Babo. Kata Tigan terinspirasi dari sebuah jembatan panjang yang menghubungkan beberapa Kampung dengan melewati aliran sungai. Aliran sungai memisahkan antara beberapa Kampung yang bertetangga. Tigan adalah kepanjangan dari "titi gantung", nama ini digunakan karena lokasi tempat kibot itu tepat berada di bawah titi gantung tersebut.

Kibot Tigan adalah milik salah seorang anggota masyarakat yang bernama Rabel. Ia memiliki latar belakang sebagai penggila seni hiburan, dimana seni hiburan ini dipelajari secara otodidak melalui alat musik piano. Bang Rabel (demikian panggilannya, 34 tahun) juga pandai bermain gitar yang dia pelajari juga secara otodidak.

Seiring berjalannya waktu Bang Rabel mulai tertarik dengan kehadiran panggung musik seperti kibot. Pada tahun 2006 dia mulai mengikuti aktivitas para pemain kibot. Bakat yang ada pada dirinya membuat Bang Rabel sering diajak bergabung bersama grup kibot yang berasal dari Kecamatan Rantau bernama Kibot XPD. Dari situlah dia mulai mengasah kemampuannya dan mulai mempelajari secara lebih mendalam tentang alat-alat musik. Hal tersebut sebagaimana penuturannya dari hasil wawancara berikut:

"Awal mulanya... sekitar tahun 2006 saya sudah ikut mereka, makanya (sekarang) saya bisa buat kibot sendiri. Kalau gitar dan piano saya belajar sendiri karena udah suka dari lajang. Cuma yang perlu kita pelajari lagi tentang arus listrik dari alat-alat kibot itu tidak sembarangan”. (Bang Rabel, Kampung Babo, 07/11/2018)

Hasil wawancara di atas menggambarkan pengalaman pemilik kibot sebelum terjun ke dunia hiburan. Setelah informan mengumpulkan modal untuk membeli alat-alat kibot sendiri yang berkisaran hingga puluhan juta rupiah, ia pun memulai usaha kibot sendiri. Awal mulanya alat-alat kibot yang dibeli adalah alat kibot bekas dari beberapa pemilik kibot di kota. Alat-alat Kibot itu dia kumpulkan di rumahnya yang merupakan sebuah kedai kopi yang menghadap ke bibir sungai tepat di bawah jembatan titi gantung.

139 | Jurnal Ilmu Sosial dan Ilmu Politik Malikussaleh (JSPM) Volume 1 Nomor 2 Tahun 2020 
Awalnya alat-alat kibot itu hanya dimainkan sebatas karokean di kedai kopinya sebagai hiburan orang-orang pulang bekerja dari berbagai aktivitas di sungai. Jalur yang paling mudah dan sering dilalui oleh masyarakat antar kampung tetangga yang saling berseberangan untuk membawa hasil sumber daya alam adalah melaui jalur air. Transportasi yang digunakan yaitu menggunakan sampan dan boat. Pelabuhan alat transportasi air tersebut tepat berada di depan kedai kopi Bang Rabel sehingga kedainya ramai pengunjung, terutama orang-orang kampung seberang.

Pada tahun 2009 alat-alat kibot Bang Rabel disewakan ke acara resepsi pernikahan, baik di sekitaran Kampung Babo maupun kampung tetangga. Kibot Tigan beroperasi ketika ada panggilan untuk bermain kibot. Menurut Bang Rabel kibotnya disewakan dimulai dari harga Rp. 1.500.000,- Rp. 2.000.000,- untuk satu kali tampil. Penghasilan dari kibot ini tidak menentu, tergantung dari banyak sedikitnya acara resepsi pernikahan atau acara-acara lainnya.

Kibot Tigan memang hanya sering beroperasi di sekitaran Kecamatan Bandar Pusaka. Terkadang tuan rumah hanya menyewa alat-alat kibotnya saja tanpa menggunakan biduan, misalnya untuk acara syukuran, arisan, dan acara lainnya. Selama kibot Tigan ini beroperasi semenjak 2009 sudah beberapa kali menggunakan biduan sebagai penyanyi atau pengiring lagu. Biduan yang dipakai oleh Bang Rabel adalah biduan yang diundangnya dari daerah luar atau dikenal dengan istilah freelance, atau bahasa umumnya "biduan lepas". Maksudnya adalah penyanyi yang tidak terikat dengan usaha kibot manapun sehingga dapat bermain di usaha kibot manapun tergantung panggilan.

Menurut informan kibot Tigan juga pernah memakai jasa biduan seksi pada awal tahun berdirinya. Penyediaan jasa biduan seksi tergantung permintaan tuan rumah, apabila dipesan maka pemilik kibot akan memanggil biduan lepas untuk manggung di kibotnya. Pada saat itu aturan terkait hiburan malam khususnya kibot belum diatur secara ketat dan tegas seperti sekarang ini sehingga hiburan malam seperti kibot masih menggunakan biduan secara bebas, baik bebas dalam berpakaian maupun bebas dalam menentukan waktu bermain malam. Semenjak tahun 2016 aksi panggung biduan seksi sudah jarang dipertontonkan, karena peraturan dan perizinan untuk hiburan kibot malam sudah diperketat. Menurut informan aktivitas hiburan kibot yang main malam semenjak 2016 sampai dengan sekarang sudah mulai menurun bahkan sembunyi-sembunyi karena ketatnya perizinan dari pihak Datok dan Polsek. Sementara aktivitas hiburan kibot di siang hari hingga sore hari masih berjalan normal seperti biasanya.

Menurut informan selama kibot Tigan ini beroperasi sejak tahun 2009 lalu tidak pernah ada komplain dari masyarakat. Kenyamanan masyarakat tidak terganggu, bahkan mereka sering datang ke kedai kopinya sambil memutarkan beberapa musik dengan volume yang disesuaikan. Menurut 
informan aktivitas kibot Tigan ini tidak terlalu mencolok karena tidak ada biduan pribadi yang menetap sehingga masyarakat melihat kibot Tigan sebagai alat hiburan saja.

Aktivitas hiburan kibot yang datang ke Kampung Babo lebih banyak berasal dari luar kampung, yaitu kibot dari Kota Tamiang atau kibot dari Sumatera Utara. Biasanya aktivitas hiburan kibot meningkat dari awal bulan Agustus sampai akhir Desember karena pada bulan-bulan tersebut biasanya banyak dilangsungkan acara resepsi pernikahan. Masyarakat percaya antara bulan-bulan tersebut adalah waktu yang baik untuk mengadakan resepsi pernikahan. Sementara di bulan-bulan yang lainnya aktivitas hiburan kibot tergantung pada acara-acara perayaan hari besar, syukuran, atau menjelang Pemilu. Menurut masyarakat aktivitas hiburan kibot yang main malam hari juga masih terjadi di Kampung Babo dan beberapa kampung tetangga, yaitu Kampung Sulum, Kampung Pengidam, Kampung Pantai Cempa, Kampung Bengkelang, dan Kampung Batu Bedulang. Hal tersebut sebagaimana penuturan dari hasil wawancara dengan Ibu Sumarsi (45) seorang ibu rumah tangga sebagai berikut:

"Di sini di kampung ini masih ada juga kibot yang maen malam, baru-baru aja pun ada di kampung seberang. Kalo menurut yang kakak tau ya, di kampung Sulum, Pengidam, Babo, Pantai Cempa, Bengkelang dan Serkel. Bisa dibilang masih lumayanlah maen malam yang penting kan jangan rusuh aja”. (Sumarsi, Kampung Babo, 08/11/2018)

Hasil wawancara di atas menunjukkan bahwa di beberapa kampung sekitar masih terdapat pelanggaran terhadap larangan hiburan kibot bermain di malam hari. Hal ini seperti yang terlihat pada gambar di bawah ini bahwa terdapat kegiatan hiburan kibot pada malam hari, lengkap dengan biduan di atas panggung sebagai penari dan penyanyi.

Gambar 1. Kegiatan Hiburan Kibot di Malam Hari dengan Beberapa Biduan pada Acara Resepsi Penikahan
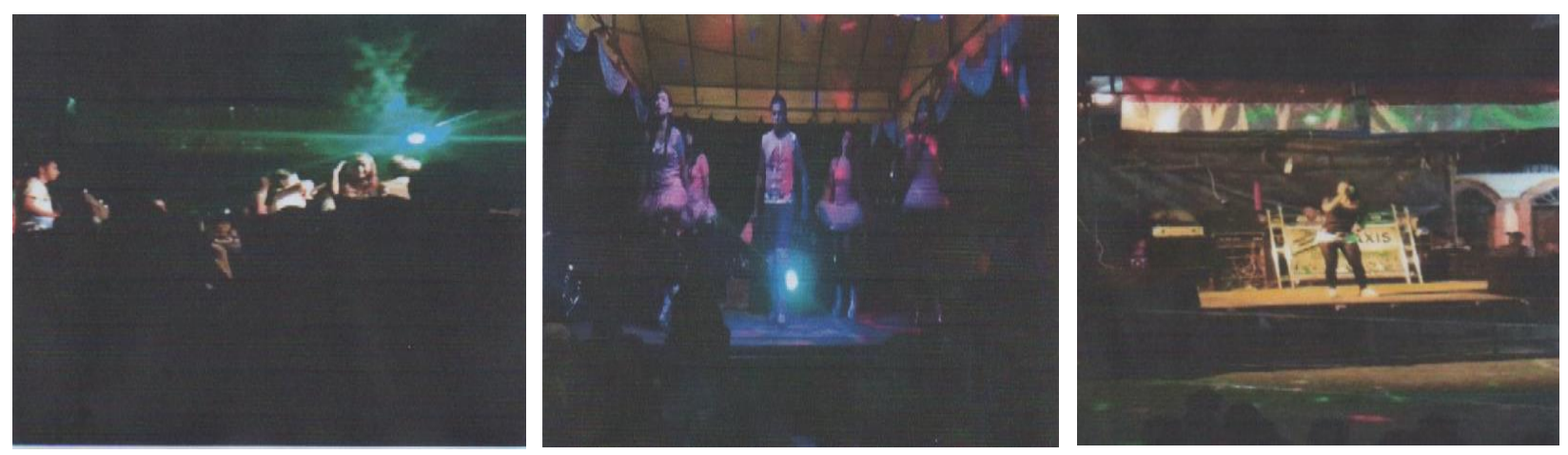

Sumber: dokumentasi penelitian, 2018. 


\section{Eksistensi Hiburan Kibot pada Masyarakat Kampung Babo}

\section{a. Eksistensi Kibot karena Faktor Ekonomi}

Hiburan Kibot yang menuai pro dan kontra tidak dapat terpisah dari pilihan yang dilakukan oleh masyarakat. Menjawab pertanyaan mengapa aktivitas hiburan kibot ini masih tetap eksis berlangsung di kalangan masyarakat salah satu penyebabnya karena faktor ekonomi. Tuan rumah pada acara resepsi pernikahan tentunya telah memiliki beberapa pertimbangan terkait hiburan apa yang akan ditampilkan pada acara tersebut. Hasil observasi menunjukkan bahwa alasan masyarakat menampilkan hiburan pada resepsi pernikahan adalah untuk mendapatkan nilai ekonomi. Hiburan dipercaya dapat meningkatkan jumlah tamu undangan, artinya meningkatnya jumlah tamu undangan akan meningkatkan nilai ekonomi yang diperoleh tuan rumah. Hal tersebut sebagaiamana penuturan dari hasil wawancara dengan Kamaliah (38) seorang ibu rumah tangga sebagai berikut:

"Menurut kakak, kalau pakai kibot akan ramai undangan yang hadir, tapi jika tidak ada kibot maka sunyi. Hanya orang-orang dekat saja yang datang, bisa balik modal juga kalau rame yang datang, kemudian pekerjaan juga banyak yang bantu”. (Kamaliah, Kampung Babo, 09/11/2018).

Informan menambahkan, apabila hiburan kibot tidak disediakan berdampak pada jumlah kehadiran tamu undangan dikarenakan hiburan kibot sebagai daya tarik untuk memeriahkan acara resepsi pernikahan. Bersadarkan teori pilihan rasional tindakan yang dilakukan oleh tuan rumah sebagai agen (pelaku) adalah bentuk dari kesadaran tuan rumah dalam memilih strategi yang dapat memaksimalkan tindakannya untuk mendapatkan sumber ekonomi sesuai dengan apa yang diharapkan. Meningkatkan jumlah tamu undangan adalah sebuah cara yang dilakukan tuan rumah dengan memanfaatkan tindakannya menampilkan hiburan kibot sehingga tujuan dari tindakan tuan rumah tercapai yaitu nilai tambah ekonomi.

Pilihan tuan rumah atas hiburan kibot tidak hanya meningkatkan jumlah tamu undangan tetapi juga memperlancar acara resepsi pernikahan dengan menjadikan hiburan kibot sebagai daya tarik masyarakat untuk bersemangat dalam bekerja. Tujuan tuan rumah dalam hal ini adalah meringankan pekerjaan untuk kelancaran acara resepsi pernikahan dengan cara menghadirkan orang banyak untuk sama-sama bekerja pada acara resepsi pernikahan tersebut. Tuan rumah dalam menentukan cara atau strategi untuk mendatangkan orang banyak harus menentukan preferensi (pilihan). Kibot dipilih sebagai sebuah strategi dari tuan rumah terhadap tujuan mereka. Hal tersebut sebagaimana penuturan informan Kamaliah (38) berikut:

"Termasuk hiburan kibot itu untuk para pekerja, istilahnya orang dapur. Supaya orang dapur itu semangat mencuci piring, begitu juga dengan yang masak. Memang jika kita 
perhatikan anak-anak muda kurang bersemangat jika tidak ada hiburan kibot. Kemudian jika hiburan itu tidak sampai malam, maka anak muda yang bekerja tadi juga tidak bekerja sampai malam, ditinggalkan begitu saja. Sebab tamu undangan itu datang sampai malam hari otomatis yang cuci piring dan masak juga sampai malam”. (Kamaliah, Kampung Babo, 09/11/2018).

Hasil wawancara di atas menunjukkan bahwa biaya yang dikeluarkan tuan rumah untuk menyewa hiburan kibot sebanding dengan hasil yang didapatkan, yaitu keberlangsungan dan kelancaran acara resepsi pernikahan di rumah mereka, karena para muda-mudi menjadikan kibot sebagai hiburan untuk bersemangat dalam membantu proses pekerjaan sampai dengan pekerjaan selesai. Dengan demikian tuan rumah tidak mengeluarkan biaya tambahan bagi orang-orang yang bekerja seperti pada umumnya di kota. Sebagaimana diketahui, pada daerah perkotaan mereka yang bekerja memasak, menyiapkan alat-alat, dan sebagainya dalam acara resepsi pernikahan akan dibayar sesuai dengan tarif mereka. Hal tersebut tidak terjadi pada masyarakat Kampung Babo, orang-orang yang sudah lelah bekerja hanya meminta disediakan hiburan oleh tuan rumah agar pekerjaan mereka diiringi hiburan kibot sehingga beban pekerjaan terasa ringan.

Berkaitan dengan jumlah uang atau "amplop" sudah tentu akan terjadi peningkatan sebanding dengan meningkatnya jumlah tamu undangan. Tidak hanya uang yang didapatkan tetapi juga "kado" atau barang-barang yang dijadikan sebagai hadiah resepsi pernikahan. Telah menjadi kebudayaan masyarakat pada umumnya setiap orang yang melangsungkan resepsi pernikahan akan diberikan hadiah baik berupa "amplop" atau "kado". Makna "amplop" atau "kado" bahkan lebih dari sekedar hadiah tetapi merupakan harapan orang-orang yang datang sebagai bekal menuju kehidupan mandiri dengan keluarga baru. Hal tersebut sebagaimana disampaikan Paimin (33) selaku Datok Kampung Babo:

“... karena kalok rame balek lagi ke keuntungan ekonomi dan masalah ekonomi. Hiburan kibot itu juga untuk orang yang rewang, yang sudah capek masak-masak di dapur. Kita sebagai tuang rumah berharap ramai yang datang, karena kan itu pernikahan. Pernikahan itu kan juga bentuk rasa syukur dan do’a restu'. (Paimin, Kampung Babo, 09//11/2018).

Hasil wawancara di atas menunjukkan bahwa faktor ekonomi tidak serta merta berkaitan dengan keuangan. Faktor ekonomi di sini juga terkait biaya yang tidak dikeluarkan terlalu besar atau penghematan biaya. Kibot menjadi alat yang multifungsi sehingga mudah digunakan dalam berbagai kegiatan, yaitu sebagai media hiburan dan alat pengeras suara yang dibutuhkan untuk serangkaian proses adat-istiadat yang dilakukan dalam acara resepsi pernikahan. Pada umumnya tuan rumah harus mengeluarkan biaya untuk hiburan dan biaya untuk alat pengeras suara, misalnya hiburan berupa pencak silat atau tarian-tarian, di samping itu juga harus menyediakan loudspeaker

143 | Jurnal Ilmu Sosial dan Ilmu Politik Malikussaleh (JSPM) Volume 1 Nomor 2 Tahun 2020 
untuk pengeras suara yang digunakan sebagai penunjang prosesi pernikahan. Jadi hiburan kibot dapat menekan sejumlah biaya yang harus dikeluarkan untuk dua unsur tersebut. Pertama sebagai hiburan, kedua sebagai alat pengeras suara.

\section{b. Eksistensi Kibot karena Faktor Nilai Sosial}

Masyarakat memandang hiburan Kibot memiliki nilai tersendiri sehingga kibot masih tetap eksis. Menurut observasi penulis yang telah disebutkan di awal penulisan, bahwa masyarakat memandang kibot itu sebagai sesuatu yang memiliki nilai kemegahan, gengsi, atau Prestise. Hal itu tergambarkan dari pernyataan Kamaliah (38) bahwa kibot itu sebagai sesuatu yang megah dan mewah sehingga menjadikan acara resepsi pernikahan lebih bergengsi. Nilai tinggi rendahnya kebergengsian itu terletak pada popularitas suatu kibot. Semakin terkenal kibotnya semakin tinggi gengsinya. Prestise tercipta karena adanya pengakuan yang diberikan oleh masyarakat (Armawi, 2011; Hambali \& Asiah, 2011). Ukuran yang digunakan masyarakat untuk menilai hiburan sebagai sesuatu yang bergengsi adalah dengan melihat tingkatan popularitas sebuah hiburan.

Persepsi semacam itu terbentuk dari penghargaan masyarakat sekitar terhadap tuan rumah ketika menerima undangan dan juga turut mengabarkan berita itu kepada orang lan. Kemudian tuan rumah juga merasa bangga karena telah mampu menghadirkan acara resepsi pernikahan dengan hiburan yang megah, sehingga hiburan megah tuan rumah tersebut dinilai sebagai tanda memiliki keadaan ekonomi yang baik. Hal yang sama juga diungkapkan oleh Bapak Ashari K.S. (45) selaku tokoh masyarakat Kampung Babo sebagai berikut :

"Ada beberapa alasan orang pakai kibot... ada yang beralasan agar ramai tamu undangannya, ada yang beralasan untuk hiburan orang kerja di dapur, ada yang beralasan jika tidak ada kibot kurang mewah, ada juga yang beranggapan pakai hiburan kibot itu bergengsi”. (Ashari K. S., Kampung Babo, 10/11/2018).

Rasa ingin menghadirkan kibot terus-menerus didorong bahkan didukung orang-orang di sekitar. Biasanya dalam sebuah resepsi pernikahan bagi tuan rumah yang tidak mampu dalam segi ekonomi akan dibantu oleh masyarakat sekitar bahkan untuk hiburan kibot yang main sampai malam hari. Hal tersebut sebagaimana penuturan dari hasil wawancara saya dengan Bang Rabel (34) pemilik Kibot Tigan berikut:

"Di sini ada juga persatuannya, misalnya siapa yang ingin pesta pernikahan anaknya pakai kibot, maka akan dibayar sama-sama. Membayar uang bersama sekitar 50.000 tiap orang sudah cukup". (Bang Rabel, Kampung Babo, 07/11/2018)

Wawancara di atas menunjukkan bahwa masyarakat masih antusias dan kompak dengan kehadiran kibot. Atas berbagai dasar alasan masyarakat berhimpun dalam sebuah persatuan yang 
tujuannya saling membantu dengan sistem gotong royong dan secara bergiliran untuk menghadirkan hiburan kibot dalam sebuah resepsi pernikahan. Menurut Kamaliah (38), semakin terkenal kibotnya semakin tinggi prestisenya. Masyarakat juga merasa terkesan apabila hiburan kibot tersebut berasal dari kibot yang mahal dan terkenal. Biasanya kibot yang terkenal itu berasal dari luar kota, pastinya dengan mengeluarkan biaya yang tinggi. Kibot dengan biaya tinggi tentunya tidak setiap tuan rumah mampu untuk menyewa. Oleh karena itu hanya sebagaian kelas ekonomi menegah ke atas yang mampu menyewa kibot luar kota dengan biaya tinggi. Hal tersebut sebagaimana penuturan dari hasil wawancara dengan informan berikut:

"Lagipula kibot yang mahal itu DJ-nya bagus dan biduannya juga cantik-cantik". (Kamaliah, Kampung Babo, 09/11/2018).

Wawancara di atas menunjukkan bahwa masyarakat masih antusias dengan kehadiran hiburan kibot yang berkualitas. Kualitas kibot juga mempengaruhi tersebar luasnya berita kepada masyarakat sekitar. Kibot yang berkualitas dipandang sebagai sesuatu yang bergengsi. Kemudian kibot yang memiliki nilai prestise yang tinggi dapat dilihat dari perbedaan kualitas DJ. Kecantikan para biduan juga dapat menjadi tolak ukur prestise sebuah kibot. Secara keseluruhan kibot dengan kualitas yang bagus tentunya didukung oleh alat-alat yang berkualitas sehingga harus dibayar dengan biaya yang tinggi.

\section{c. Eksistensi Kibot karena Faktor Tujuan Sosial}

Menurut masyarakat hiburan kibot ini dihadirkan untuk orang-orang yang sudah lelah bekerja atau "rewang" baik itu dari kalangan kaum tua maupun kaum muda-mudi. Kibot berfungsi untuk menghibur pekerja yang sudah memberikan tenaga dan meluangkan waktu dalam membantu terlaksananya resepsi pernikahan, seperti memasak, mencuci piring, dan sebagainya. Pekerjaan rewang harus dilakukan banyak orang mengingat tamu undangan yang diundang juga ramai. Mereka yang bekerja atau "rewang" sama sekali tidak diberikan upah oleh tuan rumah, akan tetapi sebagai ganti atas tenaga dan waktu mereka tuan rumah menyediakan kibot sebagai hiburan. Tuan rumah berharap resepsi pernikahan dapat berjalan dengan baik, tentunya dengan melibatkan banyak orang. Tujuannya adalah agar semua pekerjaan dapat dilakukan dengan lancar sehingga acara resepsi pernikahan dapat berjalan dengan baik sampai acara selesai. Untuk itu tuan rumah memerlukan mereka yang bekerja atau "rewang". Hal tersebut sebagaimana penuturan dari hasil wawancara dengan informan berikut: 
"Hiburan kibot menjadikan orang dapur itu semangat mencuci piring, begitu juga dengan yang masak jadi semangat. Ada lagu-lagu sehingga yang kerja tidak mudah bosan”. (Kamaliah, Kampung Babo, 09/11/2018)

Wawancara di atas menunjukkan bahwa hiburan kibot menghadirkan semangat dalam bekerja, sebagai ganti tenaga mereka yang sudah dikeluarkan. Bahkan apabila kibot itu selesai maka muda-mudi juga akan meninggalkan pekerjaanya. Oleh karena itu ketika pekerjaan belum selesai maka kibot dimainkan sampai malam sebagai hiburan untuk orang-orang yang sudah lelah bekerja. beberapa dari mereka juga ikutserta menyumbang lagu di atas panggung. Sebagian besar orang yang bekerja di acara resepsi pernikahan dari kalangan pemuda, terutama untuk mencuci piring, memasak air, dan memasak nasi, sementara kebanyakan pemuda suka dengan hiburan kibot. Barang-barang yang digunakan dalam resepsi pernikahan dibersihkan ketika acara selesai. Pada masyarakat Kampung Babo umumnya resepsi pernikahan selesai pada malam hari sehingga pemuda yang bertugas membersihkan barang-barang seperti piring, dandang, kuali, dan sejeninya dilakukan pada malam hari. Begitu juga dengan hiburan kibot yang mengiringi pemuda bekerja sampai malam. Dalam hal ini menunjukkan bahwa terdapat hubungan antara hiburan kibot dengan pemuda yang bekerja di dapur, yaitu hiburan kibot memberikan semangat bagi pemuda yang bekerja sehingga apabila hiburan kibot dihentikan maka pemuda tidak lagi bersemangat untuk bekerja bahkan bisa saja meninggalkan pekerjaanya. Hal tersebut sebagaimana penuturan dari hasil wawancara dengan Sumarsi (45) berikut:

"Kalau tuan rumah pun gak sanggup malam misalnya sampe jam 6 sore aja, anak-anak mudanya yang minta sampe malam, orang itu yang ngurusnya keamanan dan izinnya, tanggung jawab orang itu. Ketua pemudanya pun ikut juga menjaga keamanan kibot sampe malam. Itu nanti bisa sampe 200 orang yang menyumbang untuk sewa kibot”. (Sumarsi, Kampung Babo, 08/11/2018)

Sikap pemuda tersebut sebagai bentuk persatuan dan solidaritas masyarakat dalam kegiatan sosial, yang mana di sini kegiatan sosial untuk menghadirkan hiburan. Pemuda tidak hanya bekerja untuk resepsi pernikahan bahkan pemuda ikut berpartisipasi dalam penyewaan hiburan kibot, yang pada dasarnya kibot tersebut diperuntukkan bagi mereka yang bekerja. Tujuan tuan rumah telah tercapai dengan kehadiran pemuda yang membantu pekerjaan dan bahkan pemuda tidak jarang juga membantu biaya sewa kibot apabila ada penambahan waktu sewa.

\section{d. Faktor Tuntutan dari Pekerja atau Rewang}

Para pekerja atau "rewang" umunya adalah orang-orang di lingkungan tempat tinggal dan orang-orang yang mempunyai hubungan dekat dengan tuan rumah. Pekerja atau "rewang" 
diundang untuk datang sehari atau dua hari sebelum acara dimulai. Mereka yang "rewang" benarbenar menghabiskan waktu untuk membantu pekerjaan tuan rumah, terutama memasak dan menyiapkan tempat.

Para pekerja atau "rewang" akan datang ke lokasi acara pada pagi hari, bahkan pagi-pagi sekali. Baik laki-laki maupun perempuan biasanya sudah mempersiapkan diri dari rumah masingmasing untuk membantu pekerjaan. Hal itu terlihat dari para ibu yang membawa alat masak seperti pisau atau alat memasak lain untuk memudahkan pekerjaan. Begitu juga dengan bapak-bapak yang sudah membawa parang dan cangkul untuk mempersiapkan segala sesuatu yang berkaitan dengan acara. Ini adalah sebuah kearifan lokal atas dasar hubungan kekeluargaan dan persaudaraan yang erat, terlihat bagaimana masyarakat masih antusias terhadap pekerjaan yang dilakukan secara bersama-sama. Kemudian tuan rumah akan menyediakan makan dan minum bagi para pekerja atau "rewang" selain menyediakan lagu-lagu dengan sound system yang berukuran kecil sebagai penghibur para pekerja. Menurut para pekerja hiburan kecil seperti lagu-lagu bertujuan agar menjadikan suasana dalam pekerjaan lebih bersemangat. Kemudian di hari puncak resepsi pernikahan biasanya para pekerja meminta tuan rumah menyediakan hiburan kibot dengan alasan yang sama yaitu untuk menghibur diri di saat melakukan pekerjaan dan setelah lelah bekerja. Hal tersebut sebagaimana penuturan dari hasil wawancara dengan Paimin (39) selaku Datok Babo sebagai berikut:

“... yang saya lihat hiburan kibot bagi orang yang "rewang”... biasanya disediakan langsung oleh tuan rumah atau permintaan dari orang yang ngerewang". (Paimin, Kampung Babo, 09/11/2018)

Tuan rumah dalam hal ini sering tidak dapat menolak permintaan para pekerja atau "rewang" dikarenakan tenaga dari para pekerja sangat dibutuhkan oleh tuan rumah. Apabila pekerjaan mereka tidak selesai maka akan berdampak pada acara resepsi pernikahan. Kemudian dalam hal ini, pekerja atau "rewang" juga tidak memaksa hiburan kibot sebagai unsur yang wajib disediakan tuan rumah. Para pekerja atau "rewang" juga mempertimbangkan dengan kondisi ekonomi tuan rumah, apabila dari kalangan kelas ekonomi bawah mereka sudah merasa cukup dengan lagu-lagu dari sound system. Tetapi apabila tuan rumah adalah orang dengan kelas ekonomi atas maka mereka akan meminta disediakan hiburan kibot. Hiburan kibot tidak terlepas dari kemeriahan sebuah acara, terkhusus pada resepsi pernikahan. Menurut masyarakat apabila sebuah resepsi pernikahan tidak memiliki hiburan sama sekali maka acara tersebut akan terlihat sunyi. Hal tersebut sebagaimana penuturan dari hasil wawancara saya dengan Sumarsi (45) yang mengatakan bahwa:

147 | Jurnal Ilmu Sosial dan Ilmu Politik Malikussaleh (JSPM) Volume 1 Nomor 2 Tahun 2020 
"Menurut kakak, kalok pesta itu enggak ada kibotnya macam sunyi gitu. Apalagi enggak ada hiburan apa-apa, rasanya kayak bukan lagi buat acara pesta. Maunya memang pesta itu dibuat hiburannya walaupun cuman sederhana yang penting ada hiburannya... jangan sunyi kali. Kita pun yang kerja gak semangat rasanya, karena kita kalau tamu undangannya sikit kali kita masak jadi gak semangat”. (Sumarsi, Kampung Babo, 08/11/2018)

Berdasarkan hasil wawancara di atas menunjukkan bahwa tuntutan menghadirkan hiburan kibot bukan hanya saja karena permintaan pekerja atau "rewang", tuntutan tersebut berfungsi agar resepsi pernikahan menjadi tidak sunyi. Menurut informan di atas, akibat tidak ada hiburan maka resepsi pernikahan menjadi sunyi dan apabila resepsi pernikahan sunyi artinya tamu undangan juga sedikit yang hadir. Ketika tamu undangan sedikit yang hadir para pekerja atau "rewang" merasa tidak semangat untuk memasak. Hiburan yang dimaksud dapat berupa hiburan apa saja yang terpenting dapat menghibur orang ramai. Akan tetapi penulis hanya memfokuskan untuk meneliti hiburan kibot yang terkait dengan resepsi pernikahan. Hiburan kibot yang terkait atas permintaan pekerja atau "rewang" telah menjadi tugas tuan rumah, baik secara diminta atau tidak. Adapun memang tidak semua tuan rumah menghadirkan hiburan kibot, hal itu tergantung dari minat dan keadaan keuangan.

Secara tidak disadari hiburan sangat diperlukan pada sebuah acara, terutama acara resepsi pernikahan. Ibarat makan sayur tanpa garam maka akan terasa hambar, begitu juga dengan resepsi pernikahan atau acara lainnya tanpa hiburan maka acara tersebut menjadi kurang lengkap dan kurang "meriah". Hiburan kibot tidak hanya sebatas pada permintaan para pekerja atau "rewang", hiburan kibot juga mempunyai pengaruh terhadap psikologi tamu undangan karena acara tanpa hiburan akan menimbulkan banyak pertanyaan terkait mengapa sebuah acara tidak terlihat seperti sebuah acara. Dari pengamatan peneliti di beberapa acara resepsi pernikahan yang tidak menampilkan hiburan sama sekali maka acara tersebut terasa ada sesuatu yang kurang. Umumnya setiap resepsi pernikahan selalu disandingkan dengan hiburan, baik hiburan yang tradisional seperti tarian sekapur sirih, didong, dan lainnya atau juga hiburan yang lebih modern seperti band, orkes dan kibot.

\section{Pilihan Kibot sebagai Hiburan}

\section{a. Perbandingan Harga}

Hiburan kibot adalah organ tunggal yang dapat memainkan semua jenis alat musik dengan hanya menggunakan beberapa orang pemain saja. Kibot dapat dimainkan secara otomatis dengan bantuan disk, yang kemudian disk tersebut dapat diisi dengan lagu-lagu yang disukai atau disesuaikan dengan permintaan tuan rumah. Berbeda dengan hiburan lain yang harus dioperasikan 
oleh banyak orang karena satu alat musik harus dimainkan oleh satu orang pemain, sehingga jumlah alat musik akan disesuaikan dengan jumlah pemain musik (Ahira, 2005; Aley, 2011). Dalam hal ini jumlah pemain musik akan mempengaruhi harga, waktu, dan efektivitas dalam memainkannya.

Jumlah pemain musik akan mempengaruhi harga sewa sebuah hiburan, semakin banyak para pemain musik maka semakin besar biaya yang harus dikeluarkan. Ini menjadi sangat rasional karena yang pertama akan dipertimbangkan adalah bagaimana mendapatkan hiburan dengan harga yang minimum. Hal tersebut sebagaimana penuturan informan berikut:

"Menurut saya kibot itu lebih murah, lebih simple, lebih tepat karena kibot tanpa dimainkan dapat bermain sendiri (otomatis) dengan bantuan disk ketimbang hiburan lain seperti band, kuda kepang, dan lainnya”. (Paimin, Kampung Babo, 09/11/2018)

Berdasarkan hasil wawancara di atas menunjukkan bahwa dari segi harga kibot lebih murah dibandingkan dengan hiburan lain seperti band, kuda kepang, atau orkes Melayu. Dari segi efektivitas hiburan kibot lebih efektif atau mudah daripada hiburan lainnya. Hiburan Kibot tidak membawa terlalu banyak alat musik. Alat-alat musik pada hiburan Kibot juga merupakan alat musik yang dapat disatukan dalam satu wadah secara bersamaan. Keunggulan lain seperti yang disampaikan Datok Babo di atas adalah hiburan kibot lebih tepat guna. Artinya, hiburan kibot dapat dimainkan dan mengikuti keinginan tuan rumah, bahkan lagu-lagu yang dimainkan selalu dapat diupdate. Hal tersebut sebagaimana penuturan Bang Rabel (34) pemilik Kibot Tigan berikut:

"Zaman udah mudah, kibot dapat merangkap banyak jenis musik lain dengan satu alat saja. Jika Orkes banyak alat. Jika Kibot semua jenis musik bisa dimainkan. Dan juga tidak sulit karena tidak banyak alat. Otomatis banyak alat banyak pemain dan banyak biaya yang dikeluarkan. Kira-kira perbandingan harga... sewa kibot harga 2 juta sedangkan band minimal harga 5 juta". (Bang Rabel, Kampung Babo, 07/11/2018)

Artinya ada selisih harga yang sangat signifikan antara hiburan tersebut sehingga sangat rasional apabila masyarakat mempertimbangkan kibot sebagai pilihan. Kemudian dalam penuturannya Bang Rabel (34) menjelaskan secara lebih terperinci mengenai perbandingan kedua bentuk hiburan ini:

"Begitulah perbandingan orkes, band dan kibot mulai dari personilnya, alat-alat, biaya transportasi, dan gaji pemain musik. Itulah salah satu penyebab band dan orkes kalah saing dengan kibot. Personil band dan orkes minimal 10 orang, belum lagi yang angkat barang dan supir mobil. Drum, keyboard, gitar, bass, seruling, ordion, biola, loudspeaker... banyak alat banyak gaji”. (Bang Rabel, Kampung Babo, 07/11/2018)

Biaya transportasi setiap hiburan masing-masing berbeda. Jika kibot dikarenakan alatnya tidak sebanyak band dan orkes, maka dengan mobil pick up sudah cukup. Jika mengangkut alat- 
alat band dan orkes minimal menggunakan mobil truck yang tentunya biaya sewa lebih mahal. Kemudian kibot umumnya tidak membawa pekerja tambahan untuk menurunkan alat-alat musik karena dapat dikerjakan dengan bantuan orang-orang di sekitar acara. Jika band dan orkes memerlukan pekerja tambahan untuk menurunkan alat-alat musik, ditambah dengan personil yang mencapai 10 orang sehingga personil band dan orkes secara keseluruhan bisa mencapai belasan orang.

Masyarakat memiliki kebiasaan mengkhususkan hidangan makanan dan minuman beserta makanan ringan yang dihidangkan untuk para pemain musik. Perlakuan khusus ini sudah menjadi tradisi bagi tuan rumah untuk memberikan mereka makan dan minum. Pemain musik dianggap sama lelahnya dengan para pekerja di dapur. Sebagian perlakuan khusus tersebut juga permintaan dari para pemain musik. Menurut masyarakat, hal ini juga menjadi salah satu faktor melemahnya minat terhadap band dan orkes. Jika secara rasional, dalam penghitungan nilai ekonomis pelayanan khusus terhadap belasan pemain musik tidak efektif karena dianggap mengeluarkan biaya lebih, waktu, dan menambah pekerjaan tuan rumah.

Jumlah pekerja dan pemain band bila dikaitkan dengan nilai ekonomi tentunya akan berbanding jauh dengan hiburan Kibot. Apabila pada kebiasaan masyarakat, tidak hanya makan dan minum saja yang harus disediakan tuan rumah tetapi rokok juga harus disediakan tuan rumah sebagai bentuk kepedulian. Tentunya sejumlah bungkus rokok akan lebih banyak yang harus disediakan mengingat pekerja dan pemain band terdiri dari belasan orang. Hal tersebut menjadi salah satu alasan masyarakat beralih ke hiburan kibot.

Pilihan rasional terhadap nilai ekonomi diperhitungkan dengan rinci dan tepat. Kini masyarakat ingin segala sesuatu yang mudah. Oleh karena itu ketika pemain musik dianggap memperbanyak pekerjaan tuan rumah serta menambah biaya yang dikeluarkan, masyarakat menganggap hal itu bukan pilihan rasional. Nilai Ekonomi inilah yang terdapat pada hiburan kibot yang jauh lebih murah dengan pemain musik yang jauh lebih sedikit, sehingga menghemat biaya, waktu, dan tidak mempersulit pekerjaan tuan rumah dengan perlakuan khusus.

\section{b. Pembauran Musik}

Setiap saat lagu-lagu baru terus diproduksi, misalnya lagu Pop, Dangdut, Religi, Rege, Jazz, Remix, DJ, dan banyak jenis lagu lainnya. Tidak semua jenis musik dapat dimainkan dengan band dan orkes, misalnya band tidak dapat memainkan lagu DJ atau Remix karena alat yang digunakan tidak berjenis alat yang dapat mengeluarkan nada sepeti Remix dan DJ. Sementara Remix dan DJ banyak disukai oleh kalangan muda-mudi pada zaman sekarang. Remix juga dapat dikolaborasi 
dengan lagu Pop dan Regge, bahkan hampir semua jenis lagu dapat dikolaborasikan dengan Remix dan DJ. Muda mudi selalu update dengan lagu-lagu terbaru (Kurniasari, et. al., 2014), bahkan kalangan tua juga suka kolaborasi Remix dan Dangdut.

Lagu-lagu Remix Dangdut selalu update sehingga hiburan kibot dianggap tepat dan modern. Sangat banyak pilihan lagu dan nada musik dari lagu yang diinginkan cukup dengan satu alat saja, itu yang tidak dimiliki oleh jenis hiburan lainnya. Kibot juga menyediakan versi karaoke sehingga yang bukan "biduan" sekalipun dapat bernyanyi. Modernisasi hiburan yang ditawarkan kibot adalah dari jenis musik yang mengacu pada lagu-lagu terbaru.

Masyarakat ingin segala sesuatunya lebih mudah, murah, dan modern. Pembaruan musik mengikuti perkembangan zaman yang pada setiap zamannya musik terus berubah-ubah mengikuti fashion dunia. Pada kalangan masyarakat bawah yang tidak bisa menikmati konser, kibot menjadi salah satu jawaban atas keinginan masyarakat menikmati musik. Misalnya pada 2018 di Indonesia trend dengan lagu Nissa Sabyan, walaupun masyarakat bawah yang berada di daerah perkampungan tidak bisa menikmati konser secara langsung, tetapi mereka bisa menikmati musik seperti Nissa Sabyan walaupun hanya dinyanyikan oleh penyanyi biasa.

Hiburan kibot dapat menjadi solusi bagi keinginan masyarakat untuk menikmati musikmusik terbaru yang sedang menjadi trend. Menikmati musik-musik terbaru dengan harga yang murah dan dapat ditemukan dengan mudah, maka kibot adalah jawaban dari keinginan masyarakat tersebut. Kibot menjadi sarana hiburan yang dipilih masyarakat secara sadar atas dasar keuntungan secara ekonomi dan sosial. Terdapat sebuah prestise dalam masyarakat Kampung Babo karena dirasa mampu menghadirkan acara pernikahan dengan mewah dan megah. Prestise hakikatnya tidak lepas dari fitrahnya manusia, tidak terkecuali masyarakat Babo, suatu perasaan bangga terhadap hal-hal yang dianggap mewah dan megah (Bakti, et al., 2020).

Musik tradisional seperti denang sayang dan gambus adalah hal yang telah membudaya dan tidak lepas dari kehidupan masyarakat. Maka ketika muncul hiburan kibot dapat dengan mudah diterima, itu juga berkaitan dengan preferensi masyarakat yang menjadikan kibot sebagai alternatif baru karena dipandang lebih efektif dan menguntungkan sehingga dengan mudah menerima musik modern tersebut. Seni musik tidak dapat dipisahkan dari masyarakat disebabkan masyarakat sejak zaman dahulu secara turun temurun sudah mengenal dan mencintai musik baik tradisional atau modern seperti sekarang.

Adapun yang menjadi aktor dalam acara resepsi pernikahan adalah tuan rumah. Tuan rumah sebagai aktor yang memiliki pilihan untuk mencapai tujuannya. Dalam mencapai tujuannya aktor memerlukan sumber daya yaitu hiburan kibot. Tujuan daripada tuan rumah adalah "amplop" dan 
prestise. Kibot juga berfungsi sebagai daya tarik untuk para "rewangan" dan tamu undangan agar semakin banyak yang hadir, sehingga "amplop" yang didapat juga akan semakin banyak. Selain itu kibot juga dipandang sebagai sesuatu yang megah. Ketika dalam sebuah acara resepsi pernikahan menampilkan acara yang megah, di saat itulah timbul prestise dari tuan rumah sebagai salah satu tujuannya.

\section{KESIMPULAN}

Berdasarkan hasil penelitian dan pembahasan maka yang menjadi kesimpulan dalam penelitian ini sebagai berikut :

1. Eksistensi hiburan kibot pada acara resepsi pernikahan masyarakat Kampung Babo disebabkan oleh beberapa faktor, yaitu (a) Faktor ekonomi; Masyarakat menggunakan hiburan kibot sebagai hiburan dan daya tarik agar jumlah tamu undangan meningkat. Semakin meningkat jumlah tamu undangan semakin menambah nilai keuntungan yang didapatkan; (b) Faktor nilai sosial; Masyarakat memandang hiburan kibot dapat meningkatkan prestise dan bergengsi. Persepsi masyarakat terbentuk dari penghargaan orang lain kepada tuan rumah kerena dianggap mampu membuat acara yang megah; (c) Faktor tujuan sosial; Hibuan kibot menghadirkan semangat dalam bekerja dan sebagai ganti waktu dan tenaga pekerja atau "rewang" yang tidak digaji; dan (d) Faktor tuntutan pekerja "rewang"; Oleh sebab pekerja "rewang" tidak digaji maka mereka meminta agar disediakan kibot sebagai hiburan diri mereka setelah lelah bekerja dan dapat menambah gairah dalam bekerja.

2. Pilihan kibot sebagai hiburan pada acara resepsi pernikahan masyarakat Kampung Babo disebabkan oleh: (a) Adanya perbandingan harga; Hiburan kibot adalah jenis alat musik organ tunggal yang dapat memainkan semua jenis alat musik dan dimainkan oleh sedikit pemain musik serta efektif dan praktis dalam pendistribusian dan transportasi, sehingga harga yang ditawarkan jauh lebih murah dibandingkan dengan jenis hiburan lainnya; (b) Pembaruan musik; Lagu-lagu kibot selalu update atau terbaru (mengikuti trend musik) dan terdiri dari bermacam jenis musik.

\section{DAFTAR PUSTAKA}

Ahira, Y. (2005). Belajar Cepat Menguasai Keyboard. Vidi Vici. Aley, R. (2011). Siapapun Bisa Main Keyboard. Buku Biru.

152 | Jurnal Ilmu Sosial dan Ilmu Politik Malikussaleh (JSPM) Volume 1 Nomor 2 Tahun 2020 
Armawi, A. (2011). Eksistensi Manusia dalam Filsafat Sören Kierkegaard. Jurnal Filsafat, 21(1), 21-28.

Bakti, I. S., Anismar, \& Amin, K. (2020). Pamer Kemewahan: Kajian Teori Konsumsi Thorstein Veblen. Jurnal Sosiologi USK, 14(1), 81-98.

Bakti, I. S. (2020). Reification of the Signified and Consumerization of Wedding Receptions "Sintê Mungêrjê" in the Gayo Lôt Society in Central Aceh District. Sodality: Jurnal Sosiologi Pedesaan, 8(2), 15-35.

Coleman, J. S. (2008). Dasar-Dasar Teori Sosial. Nusa Media.

Hambali, Y. \& Asiah, S. (2011). Eksistensi Manusia dalam Filsafat Pendidikan: Studi Komparatif Filsafat Barat dan Filsafat Islam. Turats, 7(1), 41-56.

https://aceh.tribunnews.com (02/09/2013). Tamiang Haramkan Hiburan Keyboard sampai Malam. Diakses 3 Januari 2018 http://aceh.tribunnews.com/2013/09/02/tamiang-haramkanhiburan-keyboardsampai-malam.

https://aceh2.kemenag.go.id (15/12/2015). MPU Gelar Rakor Antarlembaga. Diakses 3 Januari 2018. https://aceh2.kemenag.go.id/berita/315016/mpu-gelar-rakor-antarlembaga?a= daftarartikel\&t=243\&lang=ar.

https://jdih.acehprov.go.id (01/01/2016). Qanun Kabupaten Aceh Tamiang Nomor 11 Tahun 2008 tentang Izin dan Tata Cara Penyelenggaraan Hiburan. Diakses 26 Januari 2018. https://jdih.acehprov.go.id/qanun-kabupaten-aceh-tamiang-nomor-11-tahun2008tentangizin-dan -tata-cara-penyelenggaraan-hiburan.

Kurniasari, N., et al. (2014). Remaja dan Musik Dangdut (Receiption Studies Musik Dangdut di Kalangan Remaja). Semiotika, 8(2), 217-256.

Moleong, L. J. (2009). Metode Penelitian Kualitatif. Remaja Rosdakarya.

Ramadhan, S. (2014). Perubahan Budaya Pertunjukan Keyboard Melayu ke Keyboard Erotis pada Acara Resepsi Pernikahan Masyarakat Tamiang (Studi di Kota Karang Baru Kabupaten Aceh Tamiang). Skripsi. FISIP Universitas Malikussaleh.

Sakrina, N. (2017). Keyboard pada Masyarakat Suku Gayo (Studi di Gampong Gajah Putih Kecamatan Gajah Puth Kabupaten Bener Meriah). Skripsi. FISIP Universitas Malikussaleh.

Soekanto, S. (2010). Sosiologi Suatu Pengantar. Rajawali Pers.

Sugiyono (2013). Metode Penelitian Kuantitatif, Kualitatif, dan $R \& D$. Alfabeta.

Suyanto, B. \& Amal, M. K. (2010). Anatomi dan Perkembangan Teori Sosial. Aditya Media Publishing.

Zai, D. (2014). Analisis Struktur Musik dan Fungsi Keyboard sebagai Musik Pengiring Tari Maena pada Upacara Pernikahan Masyarakat Nias di Kota Medan. Skripsi. Fakultas Budaya Universitas Sumatera Utara.

153 | Jurnal Ilmu Sosial dan Ilmu Politik Malikussaleh (JSPM) Volume 1 Nomor 2 Tahun 2020 